\title{
Some comments on climatic reconstructions from ice cores drilled in areas of high melt
}

\author{
Roy M. Koerner \\ Terrain Sciences Division, Geological Survey of Canada, Ottawa, Ontario K1A 0E8, Canada
}

\begin{abstract}
Poor consideration has been given in many Arctic circum-polar ice-core studies to the effect of summer snow melt on chemistry, stable-isotope concentrations and time-scales. Many of these cores are drilled close to the firn line where melt is intense. Some come from below the firn line where accumulation is solely in the form of superimposed ice. In all cases, seasonal signals are reduced or removed and, in some, time gaps develop during periods of excessive melting which situate the drill site in the ablation zone. Consequently, cross correlations of assumed synchronous events among the cores are invalid, so that time-scales along the same cores differ between authors by factors of over 2. Many so-called climatic signals are imaginary rather than real. By reference to published analyses of cores from the superimposed ice zone on Devon Ice Cap (Koerner, 1970) and Meighen Ice Cap (Koerner and Paterson, 1974), it is shown how melt affects all the normally well-established ice-core proxies and leads to their misinterpretation. Despite these limitations, the cores can give valuable low-resolution records for all or part of the Holocene. They show that the thermal maximum in the circum-polar Arctic occurred in the early Holocene. This maximum, effected negative balances on all the ice caps and removed the smaller ones. Cooler conditions in the second half of the Holocene have caused the regrowth of these same ice caps.
\end{abstract}

\section{INTRODUCTION}

Major contributions to the study of climate change have been made over the past two decades by the study of ice cores from the world's two great ice sheets of Greenland and Antarctica (e.g. Dansgaard and others, 1985, 1993; Lorius and others, 1985; Barnola and others, 1987). These ice sheets provide areas where there is positive balance and no melting. Consequently, continuous records of climate change are preserved. Studies of cores from ice caps on Spitsbergen (e.g. Gordienko and others, 1981; Punning and Tyugu, 1991; Sin'kevich, 1992; Tarussov, 1992) the Severnaya Zemlya archipelago (e.g. Kotlyakov and others, 1991) and Meighen Ice Cap (e.g. Koerner and Paterson, 1974) in the Canadian Arctic are less well known. With one exception, these records are restricted to the Holocene period. However, recognition of a climatic signal and development of time-scales in some of these cores is difficult and, at times impossible, due to heavy summer melting and the presence of time gaps in the record formed during long periods of negative balance at the drill site. Unfortunately, many of these studies have not given due consideration to the mode of accumulation and melt at the drill-site locations and its effect on the derivation of time-scales, or the interpretation of ice-core chemistry, ice texture and stable-isotope ratios in the cores. Many of these problems have already been discussed and published in work based on a core from Meighen Ice Cap (Koerner, 1968; Paterson, 1968; Koerner and others, 1973; Koerner and Paterson, 1974). I wish, therefore, to re-address the problem of ice-core analysis in cores taken from areas of high melt largely by reference to that work. Benson's (1959; see also Paterson, 1994) firn-facies terms will be used throughout.

\section{DRILL-SITE GHARACTERISTICS}

The location, elevation and surface characteristics of the drill sites to be discussed are shown in Table 1 and Figure 1. Published results from these cores are shown in Figures 2-4. Apart from the results from Meighen and Agassiz Ice Caps, the values plotted in the figures are derived from digitization of published diagrams referred to in this text. Timescales are those determined by the authors of the various publications.

\section{Canadian Arctic}

Meighen Ice Cap is a small ice cap that an ice core, drilled in 1964, showed to have accumulated almost entirely through the formation of superimposed ice (Koerner and Paterson, 1974). Mass-balance measurements have been made almost annually since 1959 and show a mean annual balance for the ice cap of $-13.2 \mathrm{~g} \mathrm{~cm}^{-2} \mathrm{a}^{-1}$. The same period has effected a slightly negative balance of $-27 \mathrm{~mm}^{-1}$ ice $\mathrm{a}^{-1}$ on the dome where the ice core was drilled. ${ }^{18} \mathrm{O}$ results from this core are shown in Figure 5.

Six surface-to-bedrock cores have been drilled from Agassiz Ice Cap in an area that lies within the percolation zone. This paper uses the combined record of two cores drilled at the top of the flowline in 1984 and 1987 as a reference for climatic change (Koerner and Fisher, 1990; Fisher and Koerner, 1994; Fisher and others, 1995) as the area does not suffer the limitations for ice-core interpretation discussed in this paper.

\section{Svalbard}

The cores on Svalbard have been drilled by the former Soviet Union (3) and the Japanese (1). The Japanese core is from the 
Table 1. Melt (in parentheses, column 5) is the product of melt per cent and annual accumulation, not balance. However, annual accumulation equals balance above the firn line. The melt values are only directly comparable between the sites if the sites lie above the saturation line. Below this, run-off occurs, i.e. melt may exceed $100 \%$ if melting extends into underlying annual layers. The two values for balance on Hoghetta include the value for the last 20 years and (in parentheses) the value for the 195963 period. The latter is the one used to date the core; Fujii and others (1990) identified recurrent layers of this thickness at depth and considered them annual layers. "Stiévenard and others (1996) believed the isotopic signature of a 37-60 cm layer of ice sandwiched between frozen sediments underlying a more recent Vavilov core represents Pleistocene ice. Somewhat contentious, it must at best represent ice that may have survived the early Holocene by its burial under protective debris. The "trend" column refers to whether the trend in either $\delta^{18} \mathrm{O}$ or melt between 7 and $0.5 \mathrm{ka}$ is significant

\begin{tabular}{|c|c|c|c|c|c|c|c|c|}
\hline \multirow[t]{2}{*}{ Site } & \multirow{2}{*}{$\begin{array}{l}\text { Elevation } \\
\text { ma.s.l. }\end{array}$} & \multirow{2}{*}{$\begin{array}{c}\text { Ice depth } \\
\text { m }\end{array}$} & \multirow{2}{*}{$\begin{array}{c}\text { Mean } \delta^{I B} O \\
\text { percent } \\
0-7 \mathrm{ka}\end{array}$} & Ice melt percent & \multirow{2}{*}{$\begin{array}{c}\text { Balance } \\
\text { mmw.e. } \mathrm{a}^{-1}\end{array}$} & \multirow{2}{*}{$\begin{array}{c}\text { Firn } \\
\text { thickness } \\
\mathrm{m}\end{array}$} & \multirow[t]{2}{*}{ Pleistocene ice? } & \multirow[t]{2}{*}{ Trend } \\
\hline & & & & $\mathrm{g} \mathrm{cm}^{-2}$ & & & & \\
\hline Agassiz' & 1730 & 127 & -27.1 & $2.9 \quad(6)$ & 98 & 60 & Yes & Yes \\
\hline Meighen $^{2}$ & 268 & 121 & -21.2 & $100 \quad(172)$ & 0 & 0 & No & No \\
\hline Hoghetta $^{3}$ & 1200 & 85.6 & $?$ & $100 \quad(200)$ & $\begin{array}{r}47 \\
(200)\end{array}$ & 0 & No & No \\
\hline $\mathrm{Fr} / \mathrm{Gron}^{4}$ & 450 & 213 & -11.3 & ? & 750 & 4 & No & No \\
\hline Lomonsov $^{5}$ & 1000 & 220 & -14.2 & ? & 820 & $27-30$ & No & No \\
\hline Austfonna $^{6}$ & 700 & 566 & -17.0 & $67 \quad(532)$ & 794 & $30-40$ & No & Yes \\
\hline Vavilov ${ }^{7}$ & 720 & 467 & -20.0 & $41 \quad(205)$ & 113 & $<10$ & $\mathrm{No}^{*}$ & No \\
\hline Akad. Nauk ${ }^{7}$ & 810 & 761 & -21.0 & $47 \quad(154)$ & 315 & ? & Yes & Yes \\
\hline
\end{tabular}

I: Fisher and others, 1995; 2: Koerner and Paterson, 1974; 3: Fujii and others, 1990; 4: Punning and others, 1980; 5: Gordienko and others, 1981; 6: Tarussov, 1992; Zagorodnov and Arkhipov, 1989; 7: Kotlyakov and others, 1991.

Høghetta ice dome on Spitsbergen (Fig. 1). No direct measurements of mass balance have been made in the vicinity of the drill site but, as the ice core drilled from there consists entirely of superimposed ice, the drill site must lie within the superimposed ice zone (Fujii and others, 1990).

The Soviet ice cores are from Vestfonna (Punning and Tyugu, 1991; Sin'kevich, 1992), Austfonna (Zagorodnov and Arkhipov, 1989; Tarrusov, 1992), the ice divide between
Gronfjord and Fridtjov Glaciers, which I will call the Gronfjord ice core (Punning and others, 1980) and Lomonosov Ridge (Gordienko and others, 1981). While accumulation rates are high, melting in summer soaks most or all of the annual layer (Lomonosov, Vestfonna and Austfonna) or occasionally removes the annual layer (Grønfjord). Thus, the drill sites are generally in the saturation zone where melt percolates deeper than the current annual layer and,

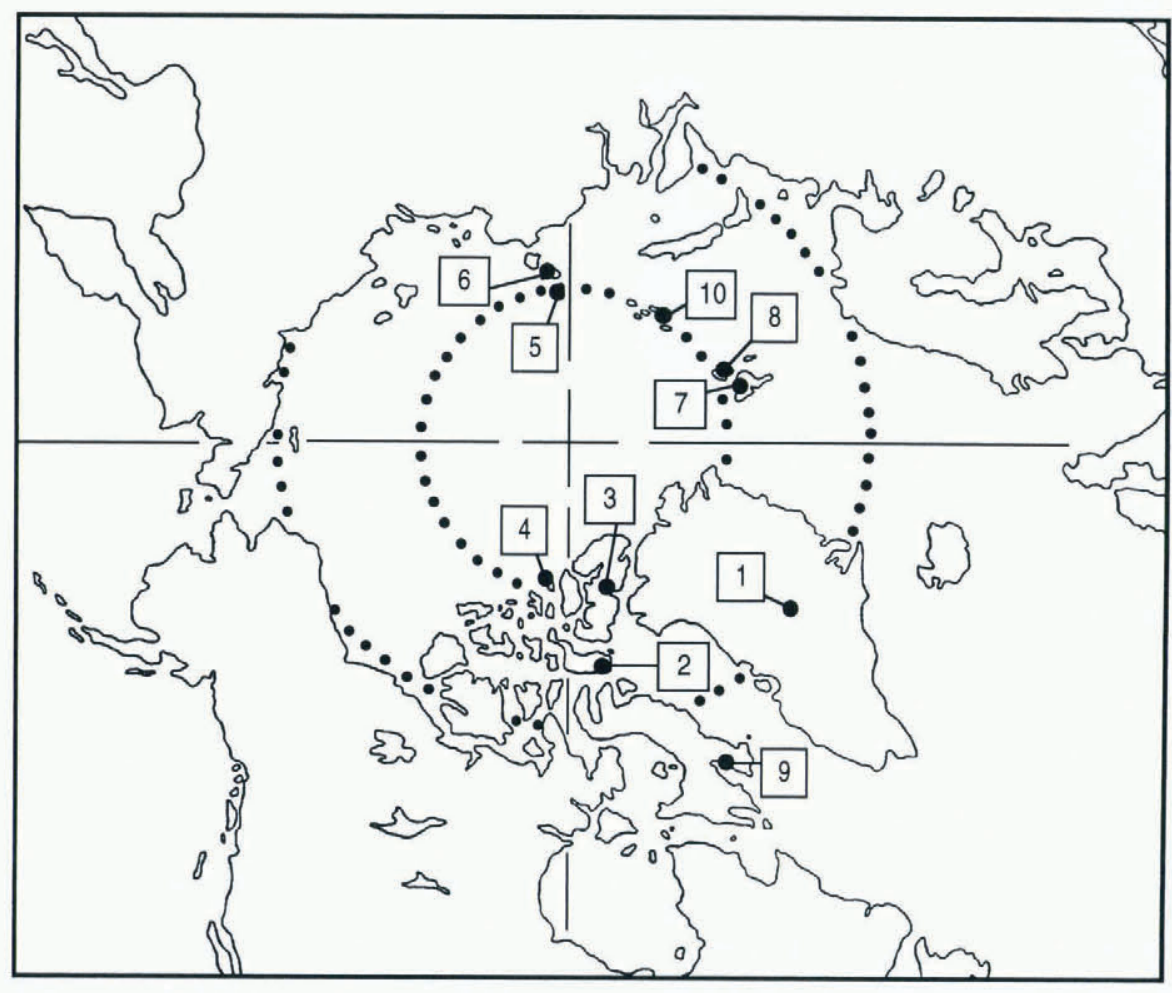

Fig. 1. Drill sites referred to in text. 1. GRIP and GISP2; 2. Devon Ice Cap; 3. Agassiz Ice Cap; 4. Meighen Ice Cap; 5. Academii

Nauk; 6. Vavilov Ice Cap; 7. Hoghetta, Gronfjord, Lomonosov; 8. Austfonna, Vestfonna; 9. Penny Ice Cap; 10. Franz Josef. 
Balance near equilibrium line

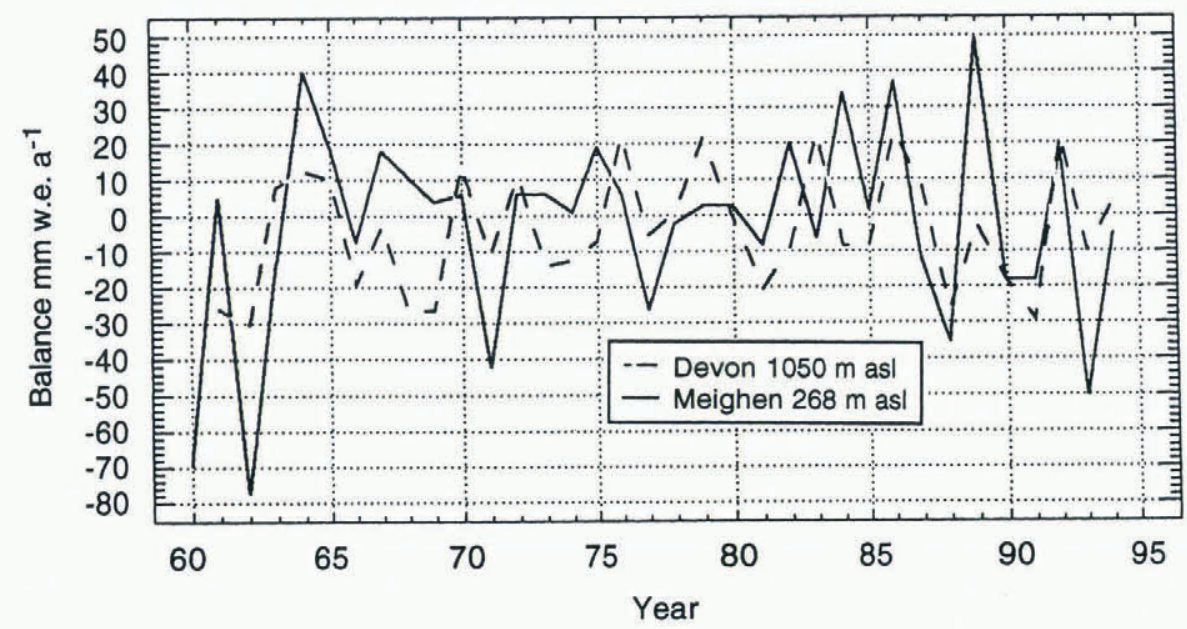

Fig. 2. Stable isotopes on a depth scale: Meighen Ice Cap (Koerner and Paterson, 1974), Lomonosov (Gordienko and others, 1981) and Gronfjord/Fridtjof (Punning and others, 1980) ice cores. Values from the Soviet ice cores are from digitization of the published records. Meighen and Gronfjord data surface to bedrock, Lomonosov surface to 20 m above the bed.

in the case of Grønfjord, occasionally in the ablation zone. Stable-isotope data from the Grønfjord and Lomonosov cores are shown in Figure 2 and melt from Austfonna is shown in Figure 4.

\section{Severnaya Zemlya}

The Severnaya Zemlya archipelago has been the centre of deep drilling by the former Soviet Union since 1975 (Kotlyakov and others, 1991). Six boreholes on the Vavilov ice dome (460-557 m) and one on Academii Nauk ice dome (AN) $(761 \mathrm{~m}$ ) have been drilled to bedrock. Both ice caps rise above the firn line (Kotlyakov and others, 1991; Barkov and others, 1992) but the accumulation undergoes substantial summer melt. The tops of both ice caps probably lie within the saturation zone as the AN ice core consists, on average, of $42 \%$ melt ice and Vavilov ice core (from Kotlya-

\section{Stable Isotopes, Svalbard, Arctic Canada}

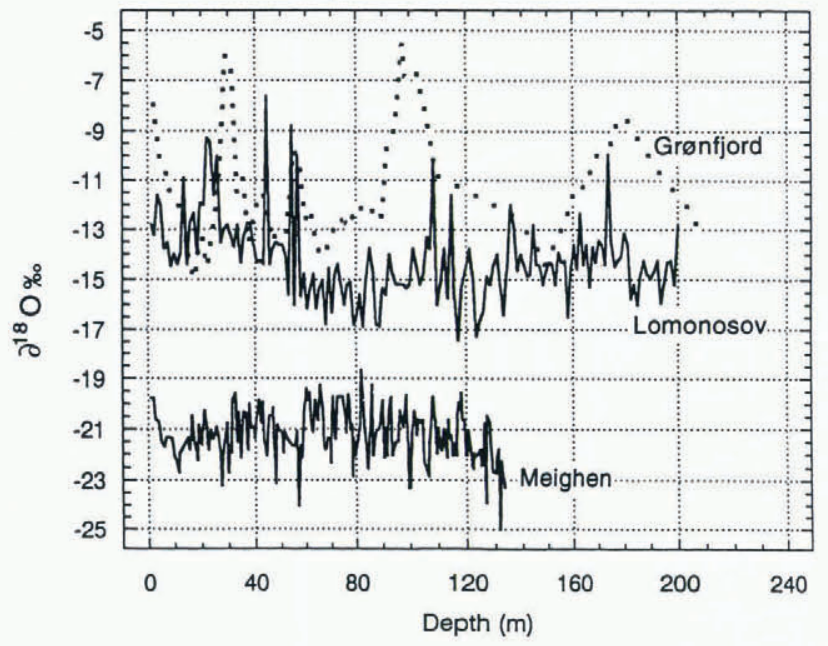

Fig. 3. Stable isotopes, Academii Nauk, Vavilov (Kotlyakov and others, 1991) and Agassiz (Fisher and others, 1983) Ice Caps. Values for Academii Nauk and Vavilov are from digitization of the published diagrams. Run-off on Vavilov (Barkov and others, 1992) has probably affected this record. kov and others, 1991) 48\% melt ice. Melt-ice percentage and stable-isotope data from Soviet cores are shown in Figures $2-4$.

\section{EFFECTS OF MELT ON ICE-CORE ANALYSIS}

\section{Stable isotopes}

Stable isotopes $\left(\delta^{18} \mathrm{O}, \delta \mathrm{D}\right)$ are used as proxy temperature indicators in ice-core analyses. The transfer function $(\delta /$ temperature) is based on empirical relationships drawn from globally distributed data (Dansgaard and others, 1973). The most important effect is that of cooling of the water vapour as it moves from its ocean source to the location where it condenses close to the ice-core site. While limitations of the transfer function have been well discussed in terms of ice cores from above the percolation line (Paterson, 1994), they are less well known for ice cores from areas of very heavy melt. The most important (and additional to those that apply above the percolation line) have been discussed by Koerner and others (1973) and are as follows.

1. Early summer melt will cause melting of the very negative (cold) $-\delta$ winter/spring snow which lies near the surface. The meltwater then percolates down to refreeze within, or at the base of, the current annual snowpack. Further melt may cause run-off of less negative (warmer) $-\delta$ snow deposited during the early winter/fall period. A very negative (cold) $-\delta$ snowpack remains.

2. Late summer melt will cause melting of surface snow deposited during the early summer period. This may percolate and refreeze in the annual snowpack. The early spring/winter snow is then exposed at the surface and further melting may cause this snow to leave the ice cap as run-off. A less negative (warmer)- $\delta$ snowpack remains.

3. Cool summers, with very little melt but accumulation of summer snow, will add a layer of less negative warmer- $\delta$ snow at the surface. This will give a disproportionately warm $\delta$ value for the annual layer. 


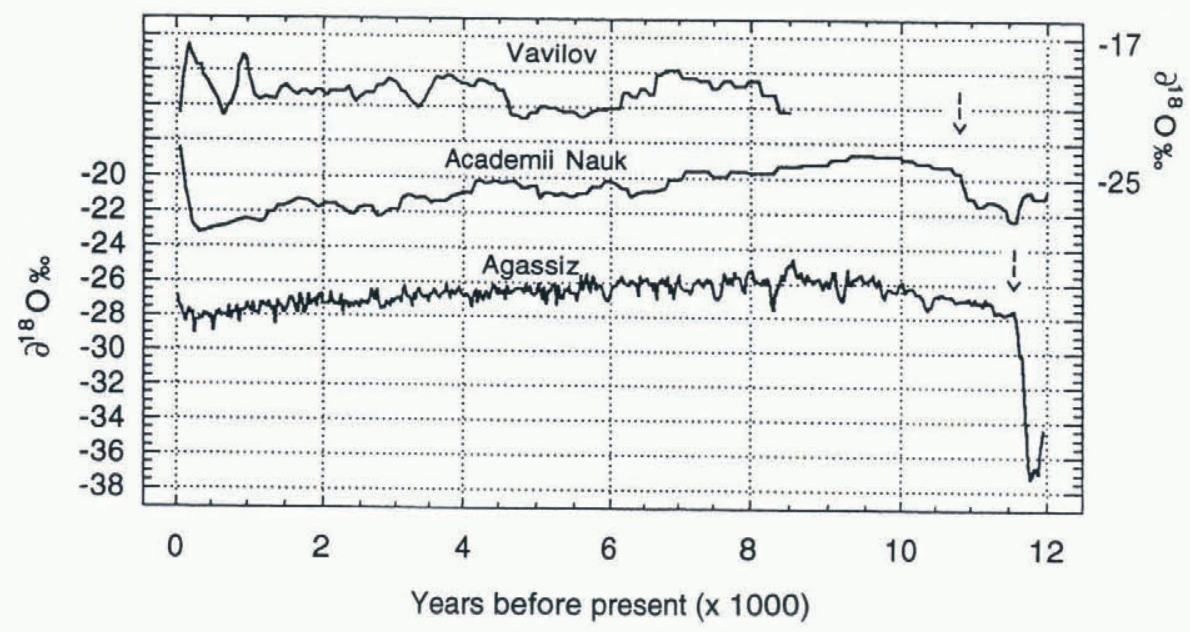

Fig. 4. Melt record for Academii Nauk (Kotlyakov and others, 1991) Austfonna (Tarussov, 1992) and Agassiz Ice Caps (Koerner and Fisher, 1990). Melt expressed as $\mathrm{g} \mathrm{cm}^{-2} a^{-1}$ based on accumulation rates and melt percentages published by the authors and, in the case of Academii Nauk, and Austfonna, digitized from the published diagram. Time-scales are those of the authors. In the case of Austfonna, both a theoretical and stratigraphic time-scale are given (Zagorodnov and Arkhipov, 1989). I use the theoretical that gives the bed an age of 6000-7000 years. The stratigraphic gives a basal ice age of 3000-4000 years.

4. Melting of the snow cover and subsequent percolation through recrystallizing snow causes isotopic fractionation and enrichment in ${ }^{18} \mathrm{O}$ of the solid phase at the expense of the meltwater (Arnason, 1969).

\section{Chemistry and wind-blown dust}

Melting causes leaching of ions in the snow pack. This postdepositional effect homogenizes the snow chemistry, thereby reducing the seasonal variations often used to detect annual layering and to date the core. Furthermore, Johannessen and others (1977), Johannessen and Henriksen (1978), Goto-Azuma and others (1993) and Gjessing and others (1993) among others have shown that some ions, such as sulphates, are preferentially leached from the snow. This means that, if meltwater leaves the drill site, the melt-

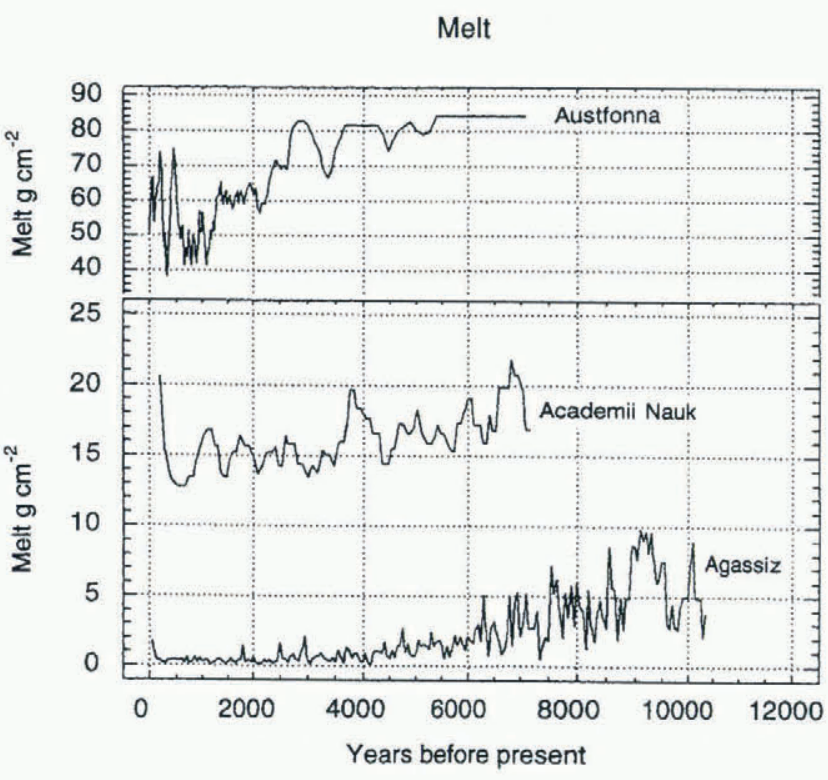

Fig. 5. Annual mass balance at the drill site on Meighen Ice Cap and at a stake situated close to the equilibrium line on the northwest side of Devon Ice Cap. water is sulphate-enriched and the remaining ice core is sulphate-depleted. We have found in work on Canadian High Arctic ice caps that, while chlorides are much less affected than sulphates by this process, intense melting will alter the position and/or amplitude of chloride spring peaks to render them unusable for recognizing annual layers; some investigators have relied on the seasonal variations of chlorides to date cores (e.g. Punning and Tyugu, 1991). Highly acid layers, formed from distant volcanic eruptions and used to date ice cores drilled from above the percolation line (Fisher and others, 1983), may also be altered sufficiently in magnitude to make them unusable for dating purposes (Fujii and others, 1990).

Insoluble microparticles tend to collect at a melting surface. With melting this produces a small peak in concentrations (Koerner, 1977). However, none of the core analyses discussed here exploits the use of microparticles for dating purposes. In some cases, this was due to a lack of adequate equipment (e.g. a Coulter counter) and in others (e.g. Meighen Ice Cap) because melting and runoff removed the scasonal cycles. Smaller ice caps are also likely to receive high inputs of wind-blown dust from the surrounding ice-free terrain. This is particularly true during winters of very low snow accumulation. Some of these particles may be soluble and will affect the ice chemistry during summer melt. Part of the increasing $\mathrm{pH} /$ time trend in the Høghetta core (Fujii and others, 1990) may be attributable to an increased input of buffering wind-blown dust with increasing depth. Koerner and Paterson (1974) related dust-layer concentrations in the Meighen core to the changing size of the ice cap. Expansion of the ice cap, for example by lowering of the firn line to ice-free ground beyond the ice-cap margins, increases the drill site-to-dust source distance; dirt-layer concentration in the core then decreases (Fig. 5; Koerner, 1968). Thus, reduction of dust concentrations may be a reflection of increased glacierization of the surrounding land.

\section{The melt-layer transfer function and ice texture}

The distribution of melt layers and the variations of ice tex- 
ture in ice cores can be used as summer-temperature proxies. The climate-related transfer function depends, in the case of ice layers, on warmer summers causing a higher percentage of melt ice in the annual layer. The transfer function is dependent on empirical relationships found in the area of investigation. For example, Koerner and Fisher (1990) used an ice per cent/elevation/temperature relationship in the Canadian High Arctic ice caps (Kocrner, 1977) to calculate a $2^{\circ} \mathrm{C}$ temperature change in the Holocene from the changing melt percentage in the Agassiz cores. The transfer function has two thresholds. The upper threshold is crossed when the zone of superimposed ice extends into the drill-site area. In this zone, all summers causing complete melting of the annual snow layer will leave a $100 \%$ melt-ice section, whether run-off occurs or not. A summer with much run-off will be warmer than one with little or none. However, the ice-core record will show a flat, $100 \%$ melt-ice record, regardless of how much run-off occurred. The lower threshold is crossed when the climate causes the dry-snow line to drop below the drill site. In this case, no melt layers are formed and there is no melt record. Both situations can be seen in two of the cores presented here; they will be discussed later. In fact, Alley and Anandakrishnan (1995) have extended this technique to dry-snow areas. By very careful examination of the GRIP Greenland core, they have developed a melt record from a core with an average of only one $2-3 \mathrm{~mm}$ thick ice layer every 200 years! Such a study demands a very high-quality ice core but extends the applicability of the method.

In the second case, i.e. in the zone of superimposed ice, where there is $100 \%$ melt ice (Meighen and Hoghetta), a climate transfer function has to be developed from ice-texture changes and is useable in only very general terms. The transfer function is based on the dependency of grain-size in the newly forming ice, on the degree of meltwater saturation of the snow cover and the temperature of the winter/spring snow pack and underlying ice during the early stages of melting (Koerner, 1970; see also Wakahama and others, 1976). At one end of the spectrum, meltwater standing on the surface at the end of the melt season freezes slowly to form very coarse-grained ice. At the other end of the same spectrum, incompletely saturated snow forms fine-grained, bubbly, ice. On Devon Ice Cap, there is a gradual transition in the superimposed ice zone, from fine-grained, bubbly ice just below the firn line to coarser-grained, clear ice just above the equilibrium line (Koerner, 1970). This change is related to the summer temperature/elevation relationship. A simple ice-core model, based on this relationship equates fine-grained bubbly ice with cold summers and coarse, clear ice with warmer summers. However, the warmest summers are unrepresented as a negative balance removes all or part of the annual accumulation. The transfer function therefore has limited application.

By similar processes, grain-size/bubble-concentration variations at one site each year may produce recognizable annual layers in the superimposed ice zone. These layers have been studied on Vestfonna by Palosuo (1987) and used by Jonsson and Hansson (1990), together with chemical and microparticle signatures, to date a shallow core from Storöya ice cap (a small island off the east coast of NordAustlandet). The latter is the only work I am aware of that has made a careful study of annual layering in superimposed ice and applied it to the development of a time-scale in the superimposed ice zone. However, continuous suites of recognizable annual layers through periods of past climatic warming must be uncommon at sites now situated near the firn line. Any period of warmer climate will create a sequence with seasons and/or complete annual layers missing. Furthermore, if at any time during the history of the ice cap, the firn line comes close to the drill site, melting will also add a layer of ice to the continuous ice under the firn $(6 \mathrm{~m}$ depth on the northwest side of Devon Ice Cap (Koerner, 1966)). In this sense, the resolution of core sections deposited just above the firn line can never be better than about $6 \mathrm{~m}$.

Koerner and Paterson (1974), although unable to detect continuous sequences of annual layers, made quantitative measurements of bubble concentrations in the Meighen core to draw inferences about climatic and slope changes at the drill site. For example, the bubbly, fine-grained ice texture of sections of the ice core 22-44 m from the surface suggested they formed during years with very cold summers. They were attributed to the Little Ice Age, despite stableisotope values that were less negative than the enclosing ice. Other studies have used qualitatively rather than quantitatively derived measurements of ice texture to detect climate signals (e.g. Kotlyakov and others, 1991).

\section{High variability of the accumulation rate}

While the snow-accumulation rate may not vary much close to the firn line, the specific mass balance does, due to fluctuations in the melt rate each summer. The 1961-93 massbalance records taken close to the mean equilibrium line on Devon and Meighen Ice Caps illustrate this (Fig. 5). Over the same period, the annual equilibrium line on Devon Ice Cap has moved between $1500 \mathrm{~m}$ a.s.l. (above the firn line) in 1962 and $<500 \mathrm{~m}$ a.s.l. (below the ice cap) in 1964,1965 and 1976. This gives a 32 year range of $>1000 \mathrm{~m}$. Any site located within this range, including those in the lower reaches of the firn zone, will have experienced years of accumulation by superimposed ice or firn, and years of mass loss. This means that some of the drill sites cited in Table 1 will include discontinuities, or time gaps.

\section{TIME-SCALES AND DISCONTINUITIES}

The main problems facing the derivation of time-scales in cores drilled close to the firn line may be summarized as follows:

1. Gaps in the record produced during periods of negative balance and the high variability of the drill-site annual mass balance limit the use of flow models (e.g. Nye, 1960) and make detailed cross-correlation between cores highly conjectural (e.g. Punning and others, 1980; Kotlyakov and others, 1991).

2. Detection of seasonal variations of ions, microparticles and stable isotopes becomes conjectural due to the effects of percolating meltwater (e.g. Gordienko and others, 1981; Punning and Tyugu, 1991).

3. Cross-correlation of volcanic events with the well-dated Greenland cores (Hammer, 1983; Hammer and others, $1985)$ is frustrated by meltwater alteration of the original signal strength of these events (e.g. Fujii and others, 1990). 
Koerner and Paterson (1974, fig. 2) drew attention to probable time gaps in the Meighen core and did not develop an overall time-scale. However, a general lack of understanding of the significance of time gaps in ice cores is common in some of the other studies. For example, Fujii and others (1990), aware of the existence of time gaps in the Høghetta core, claimed that the core included a 4000 year gap between the basal layers, where organic material was dated at c. 5000 years BP and AD 1700 when they estimated accumulation recommenced. Dowdeswell and others (1990) correctly objected to such a time gap partly on lichenometric evidence from nearby areas but also on the basis that "a very fine balance between mass inputs and outputs would have to be maintained over a very long period of time (approximately 4000 years) to preserve a $35 \mathrm{~m}$ depth of presumably stagnant ice". This is not the case. A time gap, while it represents a period of overall negative balance, need not represent one of delicate balance between positive and negative balances. The time gap may represent almost any combination of accumulation and ablation periods of varying length, as long as the total ablation during that period exceeds the total accumulation. The 4000 year time gap could include a long period of accumulation that thickened the ice cap to greater than its present dimensions followed by (or interspersed with) periods of ablation thinning the ice cap eventually to the $35 \mathrm{~m}$ level. The sole requirement is for an overall negative balance persisting for an unknown period of time and reducing the ice cap to $35 \mathrm{~m}$ thickness, followed by an overall positive balance beginning at the $35 \mathrm{~m}$ level and continuing to the present. However, no inferences may be drawn either about climatic change during that overall positive balance period (unless it can be shown to be continuous) or the sequence of events forming the time-gap discontinuity.

The Soviet cores from both Svalbard and Severnaya Zemlya suffer from questionable time-scales. A few years of recent accumulation, using nuclear fall-out layers as datum (e.g. Gordienko and others, 1981), have been over-extrapolated and variations of chemical signatures have been inappropriately considered seasonal (e.g. Vaikmyae and Punning, 1982). In addition, the possibility that sections may be missing from the cores (due to negative balance at the drill site) has not been considered in the derivation of theoretical time-scales (e.g. Punning and others, 1980; Kotlyakov and others, 1991).

The imprecision of their flow-dating methods are apparent when the basal ice in Vavilov Ice Cap has been dated at 9000 years in one case (Kotlyakov and others, 1991) and $>20000$ years in another (Vaikmyae and Punning, 1982). The Austfonna core has been given two time-scales, one theoretical and the other based on a repetitive icetexture signal which is considered annual (Zagorodnov and Arkhipov, 1989; Tarrusov, 1992). The time-scales differ by a factor of 2 at the bed.

\section{DISGUSSION}

Because of the deficiencies of earlier analyses, and the criticisms and limitations elaborated above, only a broad time frame can be established for these cores. However, important low-resolution inferences about climatic change may still be made. As a first step, I refer to the combined record of two Agassiz top-of-the-flowline cores (Fisher and others,
1995). The time-scale depends, first, on seasonal signals and, secondly, on fine-tuning by correlation of volcanic events with those in the Greenland cores and is believed correct to within $\pm 5 \%$ (Fisher and others, 1983). Secondly, I set apart the Academii Nauk ice core from the other cores discussed so far. This core shows a relatively large $\delta^{18} \mathrm{O}$ step to very negative values near its base (Kotlyakov and others, 1991). The step (Fig. 3) is very similar to the large glacial/interglacial steps in all the Greenland, Antarctic and Canadian Arctic ice cores (Fig. 1; Koerner, 1989; Cuffey and others, 1995). The $\delta$ changes below this, in the Academii Nauk core, also look similar to the Younger Dryas, Allerød and Bølling events in the Greenland and Canadian cores (Fig. 1; Koerner, 1989). The same conclusions have been drawn by Stiévenard and others (1996). In general terms, this suggests that the time-scale calculated by Kotlyakov and others (1991) may be reasonable for broad conclusions to be drawn about its Holocene record.

The AN stable-isotope and melt records are shown with those from the 1984 Agassiz core in Figures 3 and 4. All four records depict long-period cooling trends that persist through to the Little Ice Age. The Austfonna melt profile is also shown in Figure 4. This record shows a cooling trend beginning about $3 \mathrm{ka}$ ago. However, its earlier record is "flat" because melt reaches a regular $85 \%$ of the annual layer there. At this level, the record is no longer climatically sensitive (warmer summers cause run-off). The assembled records show a Holocene period with a thermal maximum early on and climate beginning to deteriorate between 8.5 and $9.0 \mathrm{ka}$. This deterioration continued intermittently and has recovered only slightly in the past 150 years.

Although not shown here, the Greenland melt profile of Alley and Anandakrishnan (1995) also shows a warmer period prior to $4 \mathrm{ka}$. So too does the "reconstructed" $\delta^{18} \mathrm{O}$ record from the Holocene part of the Greenland GRIP core (Johnsen and others, 1995). This record shows excellent agreement with the Agassiz and AN Holocene $\delta^{18} \mathrm{O}$ and melt profiles. I should point out, however, that no corrections of the GRIP type have been applied to any of these profiles.

None of the other records (Fig. 2) shows evidence of either Pleistocene ice or of a cooling trend. This indicates that they all began growth during the Holocene, probably during its second half. Further support for this argument comes from ${ }^{14} \mathrm{C}$-dated material from near the base of the Høghetta ice cap (Fujii and others, 1990) which puts the oldest ice in this ice cap loosely into the second half of the Holocene. The ice above this must, like the Meighen core, represent intermittent growth since then with most growth occurring, if we use the Agassiz/Academii Nauk/Austfonna records as guides, in the last 2-3 millennia (as Dowdeswell and others (1990) suggested). Regrowth of all the "Pleistocene ice-free" ice caps must have taken place over the last few thousand years with the smallest of them beginning regrowth most recently.

The present mass balances of three ice caps and two glaciers that have been measured for over 30 years in High Arctic Canada (Cogley and others, 1995; Koerner and Lundgaard, 1995) are slightly negative. The same is true of those glaciers that have been measured in Svalbard (Hagen and Liestol, 1990) and on Vavilov Ice Cap (Barkov and others, 1992). These negative balances have to be seen in the 
light of the melt and $\delta^{18} \mathrm{O}$ profiles from Agassiz, Academii Nauk and Austfonna Ice Caps (Figs 4 and 5) which show warmer conditions than present during the first half of the Holocene. It means that very negative balances existed throughout the first half of the Holocene in the circum-polar region. This was the period that saw the final demise of the great Pleistocene ice sheets. I would suggest that highly negative balances removed not only the great ice sheets but also many small ice caps in the circum-polar region in the early Holocene. This would explain the absence of Pleistocene ice in most of the records discussed in this paper (see Table 1).

There is other work which lends support to this argument. Lichenometric and lake-sediment analyses by Werner (1988) in the west Spitsbergen area are strongly supportive of late Holocene glacier regrowth in that region. Similarly, Bradley's (1990) synthesis of palaeoclimate studies in the Canadian High Arctic also presents a strong body of evidence for late Holocene cooling in that region. Kotlyakov and others (1991) cited evidence for restricted ice-cap extent in the Severnaya Zemlya region in the early Holocene, although they extended this period back into the late glacial as well.

\section{CONGLUSIONS}

Ice cores drilled in areas of high melt require great caution when attempting to derive palaeoclimatic information from them. Because melting can introduce time gaps and remove good seasonal signals, time-scales can be difficult or impossible to evaluate. However, I should stress that techniques for core analysis have improved enormously since many of these cores were studied. Improved detection limits of ionanalysis equipment, the use of modern microparticle counters and also of the solid electrical conductivity method associated with continuous $\mathrm{pH}$, liquid conductivity and laser/ microparticle measurements (originally discussed by Hammer (1980); Hammer, 1983) could make the study of new cores from some of these areas an important addition to the study of climatic change in the circum-polar area. The exceptionally careful work of Alley and Anandakrishnan (1995) has also shown that the "cold threshold" of melt-layer analysis can be pushed further down the temperature scale to include high-elevation Greenland cores, thereby providing further opportunities for cross-correlation with absolutely dated cores from that area.

\section{ACKNOWLEDGEMENTS}

I should like to thank two anonymous reviewers and B. Lefauconnier for very thorough reviews of the manuscript. Their suggestions have substantially improved the paper. This is Geological Survey of Canada contribution No. 43895 .

\section{REFERENCES}

Alley, R.B. and S. Anandakrishnan. 1995. Variations in melt-layer frequency in the GISP2 ice core: implications for Holocene summer temperatures in central Greenland. Ann. Glaciol., 21, 64-70.

Arnason, B. 1969. The exchange of hydrogen isotopes between ice and water in temperate glaciers. Earth Planet. Sci. Lett., 6 (6), 423-430.

Barkov, N. I. and 7 others. 1992. Novyye dannyye o stroyenii i razvitii lednika Vavilova na Servnoy Zemle [New data on the structure and development of the Vavilov ice dome, Severnaya Zemlya]. Mater. Glyatsiol. Issled. $75,35-41$.
Barnola, J. M., D. Raynaud, Ye. S. Korotkevich and C. Lorius. 1987. Vostok ice core provides 160,000 -year record of atmospheric $\mathrm{CO}_{2}$. Nature, 329 (6138), 408- 414.

Benson, C.S. 1959. Physical investigations on the snow and firn of northwest Greenland during 1952, 1953, and 1954. SIPRE Res. Rep. 26.

Bradley, R.S. 1990. Holocene paleoclimatology of the Queen Elizabeth Islands, Canadian high Arctic. Quat. Sci. Rev., 9(4), 365-384.

Cogley, J. G., W. P. Adams, M. A. Ecclestone, F. Jung-Rothenhäusler and C. S. L. Ommanney. 1995. Mass balance of Axel Heiberg Island glaciers, 1960 1991: a reassessment and discussion. Saskatoon, Sask., Environment Canada. National Hydrology Research Institute. (NHRI Science Report 6.$)$

Cuffey, K. M., G. D. Clow, R. B. Alley, M. Stuiver, E. D. Waddington and R.W. Saltus. 1995. Large Arctic temperature change at the WisconsinHolocene glacial transition. Science, 270 (5235), 455-458.

Dansgaard,W., H. B. Clausen, N. Gundestrup, S. J. Johnsen and C. Rygner. 1985. Dating and climatic interpretation of two deep Greenland ice cores. In Langway, C. C., Jr, H. Oeschger and W. Dansgaard, eds. Greenland ice core: geophysics, geochemistry, and the environment. Washington, DC, American Geophysical Union, 71-76. (Geophysical Monograph 33. )

Dansgaard, W. and 10 others. 1993. Evidence for general instability of past climate from a 250-kyr ice-core record. Nature, 364 (6434), 218-220.

Dowdeswell, J. A., D. J. Drewry and J. C. Simões. 1990. Correspondence. Comments on: "6000-year climate records in an ice core from the Høghetta ice dome in northern Spitsbergen". f. Glaciol., 36 (124), 353-356.

Fisher, D. A. and R. M. Koerner. 1994. Signal and noise in four ice-core records from the Agassiz Ice Cap, Ellesmere Island, Canada: details of the last millennium for stable isotopes, melt and solid conductivity. $\mathrm{Ho}_{\mathrm{o}}$ locene, 4(2), $113-120$.

Fisher, D. A., R. M. Koerner, W. S. B. Paterson, W. Dansgaard, N. Gundestrup and N. Reeh. 1983. Effect of wind scouring on climatic records from ice-core oxygen-isotope profiles. Nature, 301 (5897), 205-209.

Fisher, D. A., R. M. Koerner and N. Reeh. 1995. Holocene climatic records from Agassiz Ice Cap, Ellesmere Island, N.W.T., Canada. Holocene, 5(1), $19-24$.

Fujii, Y. and 10 others. 1990. 6000-year climate records in an ice core from the Høghetta ice dome in northern Spitsbergen. Ann. Glaciol., 14, 85-89.

Gjessing, Y., I. Hanssen-Bauer, Y. Fujii, T. Kameda, K. Kamiyama and T. Kawamura. 1993. Chemical fractionation in sea ice and glacier ice. Bull. Glacier Res., 11, 1-8.

Gordiyenko, F. G., V. M. Kotlyakov, Ya. -M.K. Punning and R. A. Vaikmyac. 1981. Study of a 200-m core from the Lomonosov ice plateau on Spitsbergen and the paleoclimatic implications. Polar Geogr. Geol., 5(4), $242-251$.

Goto-Azuma, K., H. Enomoto, S. Takahashi, S. Kobayashi, T. Kameda and O. Watanabe. 1993. Leaching of ions from the surface of glaciers in western Svalbard. Bull. Glacier Res., 11, 39-50.

Hagen, J. O. and O. Liestøl. 1990. Long-term glacier mass-balance investigations in Svalbard, 1950-88. Ann. Glaciol., 14, 102-106.

Hammer, C. U. 1980. Acidity of polar ice cores in relation to absolute dating, past volcanism and radio-echoes. f. Glaciol., 25 (93), 359-372.

Hammer, C. U. 1983. Initial direct current in the buildup of space charges and the acidity of ice cores. F. Phys. Chem., 87 (21), 4099-4103.

Hammer, C. U., H. B. Clausen, W. Dansgaard, A. Neftel, P. Kristinsdottir and E. Johnson. 1985. Continuous impurity analysis along the Dye 3 deep core. In Langway, C. C., Jr, H. Oeschger and W. Dansgaard, eds. Greenland ice core: geophysics, geochemistry, and the environment. Washington, DC, American Geophysical Union, 90-94. (Geophysical Monograph 33.)

Johannessen, M. and A. Henriksen. 1978. Chemistry of snow meltwater: changes in concentration during melting. Water Resour. Res., 14 (4), 615-619.

Johannessen, M., T. Dale, E. T. Gjessing, A. Henriksen and R. F. Wright. 1977. Acid precipitation in Norway: the regional distribution of contaminants in snow and the chemical concentration processes during snowmelt. International Association of Hydrological Sciences Publication 118 (Symposium at Grenoble 1975 - Isotopes and Impurities in Snow and Ice), $116-120$.

Johnsen, S. J., D. Dahl-Jensen, W. Dansgaard and N. S. Gundestrup. 1995. Greenland paleotemperatures derived from GRIP borehole temperature and ice core isotope profiles. Tellus, Ser. B, 47 (5), 624-629.

Jonsson, S. and M. Hansson. 1990. Identification of annual layers in superimposed ice from Storöyjökulen in northeastern Svalbard. Geogr. Ann., $72 \mathbf{A}(1), 41-54$.

Koerner, R. M. 1966. A mass balance study: the Devon Island ice cap, Canada. (Ph.D. thesis, University of London.)

Koerner, R. M. 1968. Fabric analysis of a core from the Meighen Ice Cap, Northwest Territories, Canada. f. Glaciol., 7 (51), 421-430.

Koerner, R. M. 1970. Some observations on superimposition of ice on the Devon Island ice cap, N.W.T. Canada. Geogr. Ann., 52A(1), 57-67.

Koerner, R. M. 1977. Distribution of microparticles in a $299-\mathrm{m}$ core 
through the Devon Island ice cap, Northwest Territories, Canada. International Association of Hydrological Sciences Publication 118 (Symposium at Grenoble 1975 - Isotopes and Impurities in Snow and Ice $), 371-376$.

Koerner, R. M. 1989. Ice core evidence for extensive melting of the Greenland ice sheet during the last interglacial. Science, 244 (4907), 964-968.

Koerner, R. M. and D. A. Fisher, 1990. A record of Holocene summer climate from a Canadian high-Arctic ice core. Nature, 343 (6259), 630-631.

Koerner, R. M. and L. Lundgaard. 1995. Glaciers and global warming. Géogr. Phys. Quat., 49(3), 429-434.

Koerner, R. M. and W. S. B. Paterson. 1974. Analysis of a core through the Meighen Ice Cap, Arctic Canada, and its paleoclimatic implications. Quat. Res. 4(3), 253-263.

Koerner, R. M., W. S. B. Paterson and H. R. Krouse. 1973. $\delta^{18} \mathrm{O}$ profile in ice formed between the equilibrium and firn lines. Nature, 245(148), Physical Science, 137-140.

Kotlyakov, V. M., V. M. Nikolayev, I. M. Korotkov and O. L. Klementyev. 1991. Klimatostratigrafiia golotsena lednikovykh kupolov Severnoi Zemli [Climate-stratigraphy of Severnaya Zemlya ice dome in the Holocene]. In Khudyakov, G.I., ed. Stratigrafiia i korreliatsiia chetvertichnykh otlozhenii Azii i Tikhookeanskogo regiona [Stratigraphy and correlation of Quaternary deposits of East Asia and the Pacific region 7. Moscow, Nauka, 100-112.

Lorius, C. and 6 others. 1985. A 150,000-year climatic record from Antarctic ice. Nature, 316 6029), 591-596.

Nye, J. F. 1960. The response of glaciers and ice-sheets to seasonal and climatic changes. Proc. R. Soc. London, Ser. A, 256 (1287), 559-584.

Palosuo, E. 1987. Ice layers and superimposition of ice on the summit and slope of Vestfonna, Svalbard. Geogr. Ann., 69A (2), 289-296.

Paterson, W. S. B. 1968. A tempcrature profile through the Meighen Ice Cap, Arctic Canada. International Association of Scientific Hydrology Publication 79. General Assembly of Bern 1967 - Snow and Ice),440-449.

Paterson, W. S. B. 1994. The physics of glaciers. Third edition. Oxford, etc., Elsevier.
Punning, Ya. -M. K. and K. R. Tyugu. 1991. Raspredeleniva khimicheskikh elementov v lednikovykh kernakh s Severo-Vostochnoy Zemli [The distribution of chemical elements in the glacier cores from Nordaust-landet]. Mater. Glyatsiol. Issled. 72, 170-176.

Punning, Ya. -M. K., R. A. Vaikmyae, V. M. Kotlyakov and F. G. Gordiyenko. 1980. Izotopno-kislorodnyye issledovaniya kerna s ledorazdela lednikov Grënf'ord i Frit'of (o. Zapadnyy Shpisbergen) [Isotope-oxygen investigations of ice core from the ice-divide of Gronfjordbreen and Fridtjovbreen (Spitsbergen) ]. Mater. Glyatsiol. Issled. 37, 173-177.

Sin'kevich, S. A. 1992. Reflection of twentieth-century climatic warming in glacier cores from Nordaustlandet. Polar Geogr. Geol., 16 (2), 114-122.

Stiévenard, M. and 6 others. 1996. Pleistocene ice at the bottom of the Vavilov ice cap, Severnaya Zemlya, Russian Arctic. F. Glaciol., 42 (142), 403-406.

Tarrusov, A. 1992. The Arctic from Svalbard to Severnaya Zemlya: climatic reconstructions from ice cores. In Bradley, R. S. and P. D. Jones, eds. Climate since A.D. 1500. London and New York, Routledge, 505-516.

Vaikmyae, R. A. and Ya. -M. K. Punning. 1982. Izotopno- geokhimiocheskiye issledovaniya na lednikovom kupole Vavilova, Severnaya Zemlya [Isotopic and geochemical studies on the Vavilov ice dome in Severnaya Zemlya]. Mater. Glyatsiol. Issled. 44, 145-149.

Wakahama, G., D. Kuroiwa, T. Hasemi and C. S. Benson. 1976. Field observations and experimental and theoretical studies on the superimposed ice of McCall Glacier, Alaska. 7. Glaciol., 16 (74), 135-149.

Werner, A. 1988. Holocene glaciation and climate change, Spitsbergen. (Ph.D. thesis, University of Colorado.

Zagorodnov, V. S. and S. M. Arkhipov. 1989. Ekspress-analiz kerna dlya izucheniya stroyeniya i temperaturnogo rezhima Vostochnogo ledyanogo polya [Express tests of the core made in order to study the structure and temperature regime of Austonna]. Mater. Glyatsiol. Issled. 66, 149158.

MS received 13 . November 1995 and accepted in revised form 11 September 1996 